\title{
Penapisan Aktivitas dan Senyawa Antidiabetes Ekstrak Air Daun Dandang Gendis (Clinacanthus nutans)
}

\author{
Yuana Nurulita1), Haryanto Dhanutirto's), Andreanus A. Soemardji ${ }^{3)}$ \\ 1) Jurusan Kimia, FMIPA, Universitas Riau, Pekanbaru 28293 \\ 2) Lab. Kimia Medisinal, Sekolah Farmasi ITB, Bandung 40132 \\ 3) Lab. Farmakologi, Sekolah Farmasi ITB, Bandung 40132 \\ Diterima 04-05-2007 Disetujui 15-12-2007
}

\begin{abstract}
An investigation of the antidiabetic activity of Aqueous Extract and its fractions from a different polarity solvent: ethanol, ethyl acetate, and n-hexane of Dandang Gendis Leaves (Clinacanthus nutans Lindau) on Mile Swiss Webster Mice has been carried out. The effect of aqueous extract of dose of 50, 100, and $150 \mathrm{mg} / \mathrm{kg} \mathrm{BW}$ was tested on glucose serum level of alloxan induced that mice. Its fractions were tested by glucose tolerance method. Aqueous extract (150 mg/kg BW) significantly decreased blood glucose serum level (pd" 0,05$)$ that had the same effect as oral glibenclamide $(0,65 \mathrm{mg} / \mathrm{kg} \mathrm{BW})$ administrated once a day for 9 days. Aqueous extract that was fractionated has 5 fraction. Fraction of ethanol extract that was insoluble in ethyl acetate at a dose of $100 \mathrm{mg} / \mathrm{kg}$ BW was the most active fraction, that significantly $(p<0,05)$ decreased blood glucose serum level of mice at glucose tolerance method of 18,4\% in 3 hours after $2 \mathrm{~g} / \mathrm{kg} \mathrm{BW}$ of glucose administration. Thin layer chromatography (TLC) of that fraction ethanol 95\%-chloroform 9:2 as eluent gave 5 spots under ultraviolet ray and showed spesific compounds by qualitative test. Spot 1 (steroid) gave Rf 0,14; spot 2 and spot 3 that gave Rf 0,53 and 0,67 were flavonoid, spot 4 (triterpenoid) gave $R f 0,77$; and spot 5 (chlorophyll) gave $R f 0,89$. This research show that this plant can used for hipoglicemic traditional medicine.
\end{abstract}

Keywords: antidiabetic, dandang gendis leaves, diabetes mellitus, extract, fractions.

\section{PENDAHULUAN}

Obat tradisional dari bahan alam dapat menjadi salah satu alternatif pengobatan apalagi di tengah situasi perekonomian di mana salah satu konsekuensinya adalah tinggi harga obat sintetik. Meskipun banyak senyawa kimia organik sintetik telah tersedia untuk penggunaan pengobatan berbagai penyakit, tetapi sangatlah penting untuk mencari alternatif obat baru yang memungkinkan efektivitas pengobatan yang lebih baik dan diharapkan mempunyai efek samping minimal, salah satunya obat yang diekstrak dari tumbuhan.

Banyak tumbuhan Indonesia digunakan secara tradisional sebagai antidiabetes, salah satunya adalah daun dandang gendis (Clinacanthus nutans). Penelitian efek fisiologis terhadap tanaman dandang gendis telah dilakukan oleh Sugiri (1980) dengan hasil bahwa ekstrak air daun dandang gendis dapat menurunkan gula darah hewan coba menggunakan metoda toleransi glukosa dengan keaktifan sebesar $64,77 \%$ dibandingkan tolbutamid. Untuk mengetahui efek ekstrak daun dandang gendis yang dapat menurunkan kadar gula darah pada hewan coba diabetes belum diuji. Selain itu, Andarini (1990) mengungkapkan bahwa ekstrak air daun dandang gendis sampai dengan dosis $4250 \mathrm{mg} /$ $\mathrm{kg}$ bobot badan (sekali sehari selama 3 bulan) tidak menimbulkan efek hepatotoksik yang berarti pada tikus. Hasil skrining fitokimia oleh Natalia (1992) diketahui bahwa dalam daun dandang gendis terdapat senyawa golongan alkaloida, saponin, dan minyak atsiri. Penelitian ini mencoba menguji efek pemberian ekstrak air daun dandang gendis dan fraksi-fraksinya dalam menurunkan kadar gula darah pada tikus diabetes induksi aloksan sehingga dapat diketahui golongan senyawa yang berperan dalam menurunkan kadar gula darah.

\section{BAHAN DAN METODE}

Bahan Tanaman. Sampel yang digunakan dalam penelitian ini adalah daun dandang gendis yang didapat dari Lembang, Bandung. Bahan ini dideterminasi di laboratorium Taksonomi Tumbuhan, Sekolah Tinggi IImu Hayati, Institut Teknologi Bandung. Rajangan daun setelah dikeringkan di bawah sinar matahari selama beberapa hari, ditumbuk hingga halus dan siap digunakan.

Hewan Coba. Pada penelitian ini digunakan mencit jantan Swiss webster yang diperoleh dari 


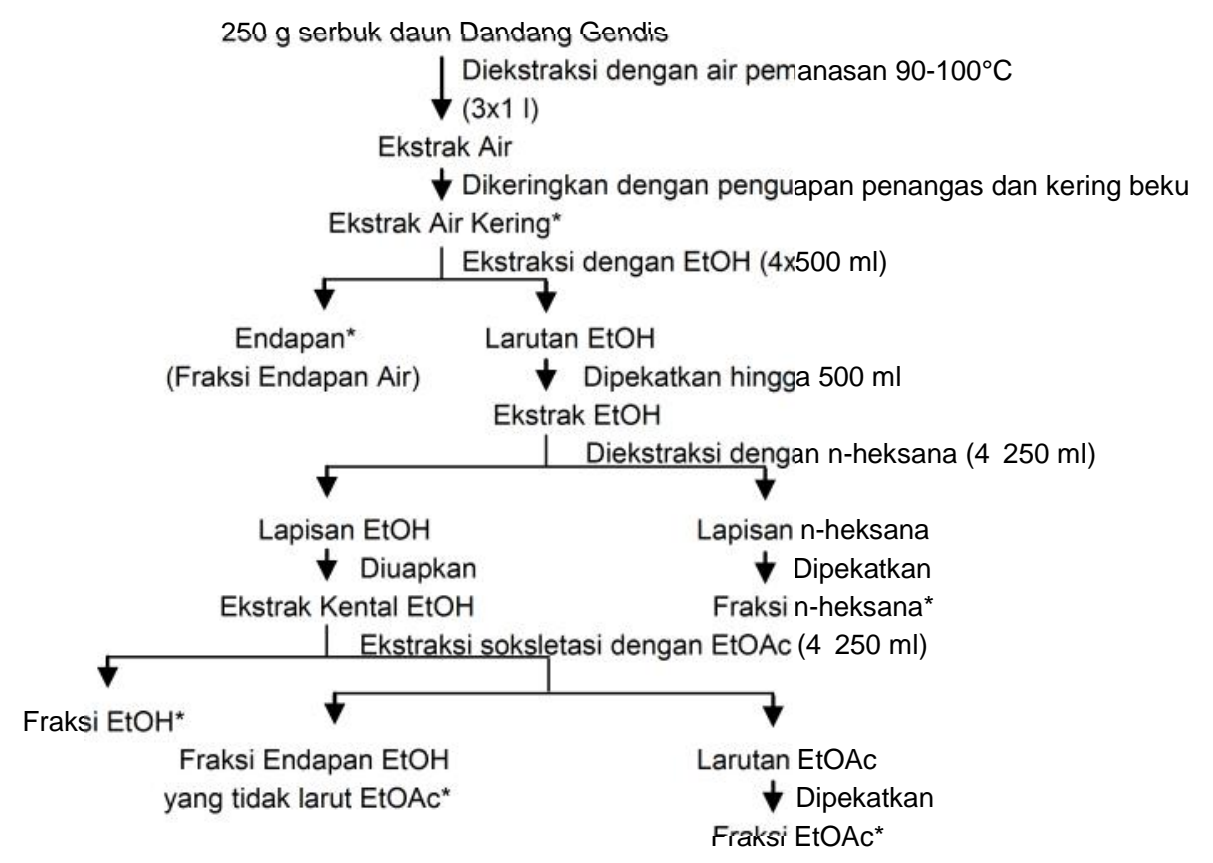

* Ekstrak dan fraksi yang diuji pengaruhnya pada kadar glukosa darah mencit dengan metoda toleransi glukosa

Gambar 1. Skema ekstraksi dan fraksinasi daun dandang gendis (Clinacanthus nutans)

Laboratorium Hewan Unit Bidang Farmakologi Farmasi ITB dengan bobot 25-35 gram dan berusia 3 bulan. Mencit diabetes yang digunakan adalah mencit normal yang diinduksi dengan aloksan $50 \mathrm{mg} / \mathrm{kg}$ bb secara intravena. Setelah tiga hari mencit normal menjadi diabetes dan dipilih yang memiliki kadar glukosa darah besar dari $200 \mathrm{mg} / \mathrm{dl}$.

Rancangan Percobaan. Ekstraksi bahan uji, simplisia daun dandang gendis, dilakukan dengan pelarut air dan difraksinasi lebih lanjut dengan pelarut polar, semi polar, dan non polar (Gambar 1). Ekstrak air diuji pengaruhnya pada penurunan kadar glukosa darah mencit diabetes dengan pembanding glibenklamid dosis lazim yaitu setara $5 \mathrm{mg}$ untuk manusia dengan faktor konversi $0.0026 / 20 \mathrm{~g}$ bb mencit (Laurence \& Bacharach, 1964). Ekstrak hasil fraksinasi diuji lebih lanjut dengan metode toleransi glukosa pada mencit normal. Fraksi yang paling berpotensi dipisahkan lebih lanjut dengan kromatografi preparatif.

Ekstraksi dan Fraksinasi Senyawa Aktif Daun Dandang Gendis. Serbuk daun dandang gendis dengan bobot $250 \mathrm{~g}$ diekstraksi dengan air pada suhu 90-100 $\mathrm{C}$ selama 15 menit. Ekstraksi dilakukan triplo dengan volume masing-masing 1 liter. Ekstrak dikeringkan dengan cara penguapan penangas dan dikeringbekukan untuk mendapatkan ekstrak Air.
Ekstrak Air diekstraksi dengan etanol yang dilakukan triplo dengan volume etanol masing-masing $500 \mathrm{ml}$ dan didapat endapan dan larutan etanol. Larutan etanol dipekatkan hingga $500 \mathrm{ml}$ dan diekstraksi cair-cair dengan $n$-heksan sebanyak 4 kali dengan volume masing-masing $250 \mathrm{ml}$. Kemudian lapisan etanol dikeringkan sehingga didapat endapan ekstrak etanol diekstraksi lebih lanjut dengan etilasetat secara soksletasi 4 kali dengan volume masing-masing 250 ml. Lapisan $n$-heksan dan filtrat etilasetat dipekatkan maka didapat ekstrak n-heksan dan ekstrak etilasetat (Gambar 1). Ekstrak air, fraksi ekstrak air yang tidak larut etanol (fraksi endapan air), fraksi etanol, fraksi ekstrak etanol yang tidak larut dengan etilasetat (fraksi endapan etanol), fraksi etilasetat, dan fraksi n-heksan diuji pengaruhnya pada kadar glukosa darah mencit normal metode toleransi glukosa. Selain itu keenam ekstrak dan fraksi diuji kandungan fitokimianya. Ekstrak hasil fraksinasi yang paling aktif dipisahkan dengan kromatografi preparatif menggunakan eluen yang dapat memisahkan dengan baik hasil percobaan pendahuluan (etanol 95\%-kloroform 9:2).

Pengukuran Glukosa Darah. Pengukuran dilakukan dengan menggunakan metode tes kolorimetri enzimatik dengan deproteinisasi, yaitu dengan menggunakan kit glukosa GOD-PAP berdasarkan 
metode glukosa oksidase. Penentuan kadar gula darah menggunakan spektrofotometer Hitachi 4020 pada panjang gelombang $546 \mathrm{~nm}$.

Pengukuran Glukosa Darah dengan Kit Glukosa GOD-PAP. Darah mencit diambil melalui ekor sebanyak 0,5-1 $\mathrm{ml}$ ke dalam tabung ependorf. Darah disentrifusa selama 10 menit untuk diambil serumnya sebanyak $50 \mu \mathrm{l}$ dan kemudian ditambahkan uranil asetat $500 \mu \mathrm{l}$ dan disentrifusa kembali. Supernatan sebanyak $50 \mu \mathrm{l}$ diambil dan ditambahkan pereaksi enzim kit glukosa $500 \mu \mathrm{l}$, kemudian diinkubasi selama 10 menit dan diukur dengan spektrofotometer Hitachi 4020 pada panjang gelombang $546 \mathrm{~nm}$ untuk mendapatkan nilai kadar glukosa darah. Hal yang sama dilakukan untuk blanko dan standar glukosa.

Uji Efek Ekstrak Air Daun Dandang Gendis pada Kadar Glukosa Darah Mencit Diabetes dengan Pembanding Glibenklamid. Hewan uji dibagi 3 kelompok yang masing-masing kelompok terdiri 5 ekor mencit diabetes yaitu mencit diabetes sebagai kontrol, mencit diabetes yang diberikan ekstrak air, dan mencit diabetes yang diberikan pembanding glibenklamid. Mencit diabetes dari masingmasing kelompok dipuasakan selama 18 jam. Diberikan bahan-bahan secara oral setiap hari selama 9 hari. Pengambilan darah dan pengukuran kadar glukosa darah mencit dilakukan dengan kit glukosa enzimatik dilakukan setiap 3 hari sekali.

Uji Efek Fraksi Ekstrak Air Daun Dandang Gendis pada Kadar Glukosa Darah Mencit Normal dengan Metoda Toleransi Glukosa. Penapisan Ekstrak dan Fraksi Daun Dandang Gendis terhadap Kadar Glukosa Darah Mencit Normal dengan Metode Toleransi Glukosa. Mencit dibagi atas 7 kelompok masing-masing terdiri dari 3 ekor yaitu mencit kontrol, mencit yang diberikan ekstrak air, mencit yang diberikan fraksi endapan ekstrak air yang tidak larut etanol, mencit yang diberikan fraksi etanol, mencit yang diberikan fraksi etilasetat, mencit yang diberikan endapan etanol yang tidak larut etilasetat, dan mencit yang diberikan fraksi n-heksan. Masing-masing kelompok mencit dipuasakan selama kurang lebih 18 jam dan diberikan bahan-bahan obat secara oral. Dosis bahan obat yang digunakan adalah $100 \mathrm{mg} / \mathrm{kg}$ bb. Sejam setelah itu diberikan secara oral glukosa dengan dosis $2 \mathrm{~g} / \mathrm{kg}$ bb. Untuk penentuan kadar glukosa darah mencit diambil darah pada jam ke-0 sebelum pemberian bahan obat, dan jam ke-1, 2, dan 3 setelah pemberian glukosa. Pengukuran kadar glukosa darah mencit dilakukan dengan kit glukosa enzimatik.

Pemisahan Fraksi Aktif Daun Dandang Gendis dengan Kromatografi Preparatif. Fraksi endapan etanol merupakan fraksi yang paling aktif yang diperiksa dan dipisahkan lebih lanjut. Pertama menggunakan kromatografi lapis tipis (KLT) untuk memilih eluen dengan pemisahan komponen yang terbaik, dilanjutkan dengan kromatografi preparatif untuk mengumpulkan fraksi dan akan diuji efek hipoglikemik lebih lanjut. Pemisahan fraksi aktif menggunakan pengembang etanol 95\%-kloroform 9:2 memberikan 5 noda di bawah lampu ultraviolet. Isolasi ke-5 noda dilakukan dengan kromatografi preparatif ukuran $10 \times 20 \mathrm{~cm}$ yang menghasilkan 5 fraksi.

Uji Statistika. Data glukosa darah yang didapat diolah secara statistika dengan metode uji software SPSS untuk mengetahui perbedaan bermakna dari setiap kelompok pada $\mathrm{P}<0,05$ terhadap kelompok kontrol.

\section{HASIL DAN PEMBAHASAN}

Pada penelitian ini digunakan bahan uji berupa simplisia kering daun dandang gendis (Clinacanthus nutans) yang digodok pada suhu $90-100^{\circ} \mathrm{C}$ sebagai pendekatan pengolahan tumbuhan obat atau jamu secara tradisional (cara penyiapan tumbuhan obat atau jamu di masyarakat adalah secara perebusan dalam air pada suhu tinggi dan waktu tertentu). Ekstrak air diuji pengaruhnya pada kadar glukosa darah mencit diabetes induksi aloksan dengan pembanding glibenklamid. Bobot badan mencit diabetes uji selama 9 hari perlakuan cenderung berubah-ubah tetapi tidak berubah nyata secara statistik pada $\mathrm{P}<0,05$

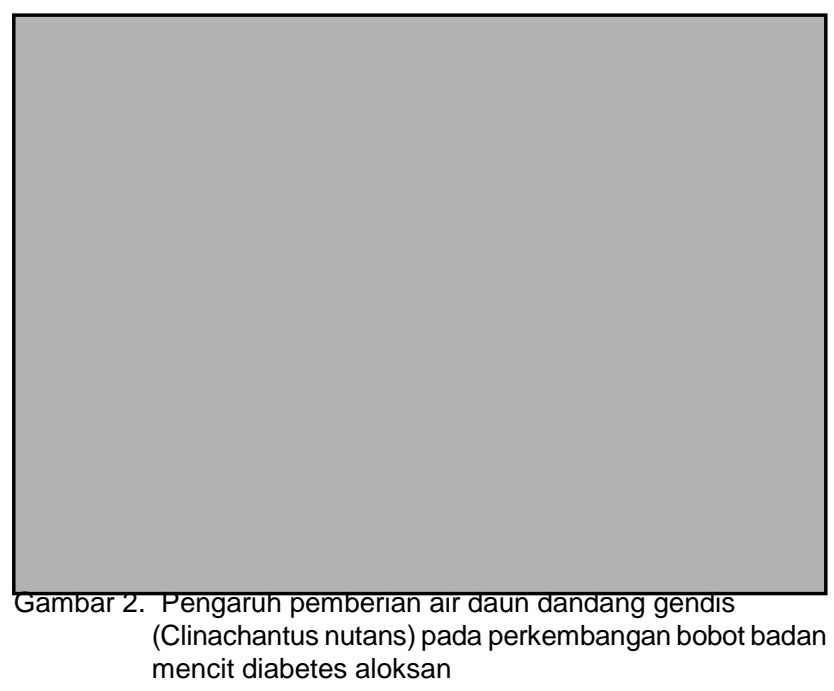


Tabel 1. Hasil pemeriksaan kadar glukosa darah mencit diabetes aloksan

\begin{tabular}{|c|c|c|c|c|c|c|c|c|c|}
\hline \multirow[t]{2}{*}{ Kelompok } & \multicolumn{5}{|c|}{$\begin{array}{l}\text { Rataan } \pm \text { SD Kadar Glukosa Darah Mencit } \\
\qquad(\mathrm{mg} / \mathrm{dl})\end{array}$} & \multicolumn{4}{|c|}{$\begin{array}{c}\text { Persentase Perubahan } \\
\text { Kadar Glukosa Darah Mencit } \\
(\%)\end{array}$} \\
\hline & 0 & 2 jam & 3 hari & 6 hari & 9 hari & $\Delta 2$ jam & $\Delta 3$ hari & $\Delta 6$ hari & $\Delta 9$ hari \\
\hline Kontrol & $442 \pm 134$ & $469 \pm 159$ & $412 \pm 168$ & $478 \pm 194$ & $439 \pm 217$ & $4.7 \pm 8.9$ & $-9.1 \pm 17$ & $5.8 \pm 18$ & $-4.9 \pm 22$ \\
\hline Ekstrak Air (150 mg/kg BB) & $442 \pm 149$ & $429 \pm 174$ & $356 \pm 79$ & $340 \pm 91$ & $195 \pm 66^{a}$ & $-4.9 \pm 14$ & $-13.6 \pm 24$ & $-18.4 \pm 23$ & $-53 \pm 15^{a}$ \\
\hline Glibenklamida $(0,65$ mg/kg BB) & $425 \pm 76$ & $422 \pm 80$ & $437 \pm 123$ & $387 \pm 116$ & $207 \pm 92^{a}$ & $0.8 \pm 21$ & $2.5 \pm 20$ & $-9.6 \pm 19$ & $-52 \pm 17^{a}$ \\
\hline
\end{tabular}

Keterangan: ${ }^{a}$ berbeda nyata dibandingkan dengan kadar glukosa darah kelompok kontrol pada $\mathrm{P}<0.05$ $\mathrm{n}=5$ ekor

(Gambar 2). Dosis induksi aloksan yang digunakan 50 $\mathrm{mg} / \mathrm{kg}$ bb dalam natrium klorida fisiologis dengan harapan kerusakan pankreas tidak $100 \%$ sehingga sintesis dan sekresi insulin tetap ada dan model hewan diabetes dapat mendekati diabetes tipe II. Tiga hari setelah induksi aloksan, kadar glukosa darah mencit meningkat dari rata-rata $106,85 \pm 22,18 \mathrm{mg} / \mathrm{dl}$ menjadi $450,56 \pm 107,06 \mathrm{mg} / \mathrm{dl}$ yang berarti mencit menjadi diabetes. Hewan uji dibagi atas 3 kelompok, yaitu kontrol yang diberi air suling ganda, ekstrak air daun dandang gendis $150 \mathrm{mg} / \mathrm{kg} \mathrm{bb}$, dan pembanding glibenklamid $0,65 \mathrm{mg} / \mathrm{kg} \mathrm{bb}$. Perlakuan ini dilakukan setiap hari 1 kali sehari selama 9 hari. Dua jam setelah perlakuan, kelompok bahan uji dan glibenklamid telah memberikan penurunan kadar glukosa darah tetapi tidak berarti $(P<0,05)$, sedangkan kontrol justru mengalami peningkatan kadar glukosa darah. Pengamatan hingga hari ke-6, bahan uji telah memberikan penurunan kadar glukosa darah yang berarti $(P<0,05)$ terhadap kontrol yaitu turun $104,56 \pm 113,96 \mathrm{mg} / \mathrm{dl}$, sedangkan glibenklamid belum menunjukkan penurunan kadar glukosa darah yang berarti terhadap kontrol $(P<0,05)$. Pengamatan hingga hari ke-9, terlihat bahwa ke-2 bahan memberikan penurunan kadar glukosa darah yang berbeda secara statistik terhadap kontrol $(P<0,05)$ di mana bahan uji memberikan penurunan $-248,54 \pm$
$115,40 \mathrm{mg} / \mathrm{dl}$ dan pembanding glibenklamid memberikan penurunan $-218,26 \pm 61,18 \mathrm{mg} / \mathrm{dl}$. Disini dapat dilihat bahwa ternyata bahan uji memberikan penurunan $2 \%$ lebih besar dibandingkan glibenklamid pada hari ke-9 tetapi tidak berbeda secara nyata (Tabel 1).

Setelah dibuktikan bahwa ekstrak air bahan uji memberikan efek antidiabetes, ekstrak tersebut difraksinasi lebih lanjut dengan menggunakan beberapa pelarut dari pelarut polar hingga non polar. Hal ini merujuk agar menarik senyawa aktif tersebut dalam pelarut polar, pelarut semi polar, dan pelarut non polar. Terhadap setiap fraksi beserta endapan yang diperoleh dilakukan penapisan fitokimia dan efeknya terhadap kadar glukosa darah mencit normal dengan metoda toleransi glukosa. Hasil uji fitokimia didapat bahwa ekstrak air bahan uji dan kelima fraksinya (fraksi Etanol, fraksi endapan air, fraksi Etilasetat, fraksi endapan $\mathrm{EtOH}$, dan fraksi n-Heksan) mengandung alkaloid, steroid/triterpenoid, dan tanin. Flavonoid dimiliki keempat fraksi kecuali fraksi n-Heksana (Tabel 2). Golongan senyawa yang didapat mendukung penelitian Natalia (1992) bahwa tanaman ini mengandung alkaloid.

Ekstrak air dan fraksi-fraksi daun dandang gendis diuji pengaruhnya terhadap kadar glukosa darah mencit

Tabel 2. Hasil penapisan fitokimia ekstrak dan fraksi daun dandang gendis (Clinacanthus nutans)

\begin{tabular}{|c|c|c|c|c|c|c|}
\hline Pemeriksaan & Ekstrak Air & $\begin{array}{c}\text { Fraksi } \\
\text { endapan } \\
\text { yang tidak } \\
\text { larut EtOH }\end{array}$ & Fraksi EtOH & Fraksi EtOAc & $\begin{array}{c}\text { Fraksi } \\
\text { endapan } \\
\text { EtOH yang } \\
\text { tidak larut } \\
\text { EtOAc }\end{array}$ & $\begin{array}{c}\text { Fraksi } \\
\text { n-Heksana }\end{array}$ \\
\hline Alkaloid & + & + & + & + & + & + \\
\hline Saponin & - & - & - & - & - & - \\
\hline Flavonoid & + & + & + & + & + & - \\
\hline Tanin & + & + & + & + & + & + \\
\hline Kuinon & - & - & - & - & - & - \\
\hline
\end{tabular}


Tabel 3. Hasil pemeriksaan kadar glukosa darah mencit dengan Metoda Toleransi Glukosa

\begin{tabular}{|c|c|c|c|c|}
\hline \multirow[t]{2}{*}{ Kelompok } & \multicolumn{4}{|c|}{$\begin{array}{c}\text { Rataan } \pm \text { SD Kadar Glukosa Darah Mencit }(\mathrm{n}=3) \\
(\mathrm{mg} / \mathrm{dl})\end{array}$} \\
\hline & 0 & 1 jam & 2 jam & 3 jam \\
\hline Kontrol & $69.03 \pm 11.46$ & $\begin{array}{l}119.89 \pm 34.39 \\
(72,19 \%)\end{array}$ & $\begin{array}{l}114.63 \pm 65.43 \\
(61,20 \%)\end{array}$ & $\begin{array}{l}142.10 \pm 32.03 \\
(105,20 \%)\end{array}$ \\
\hline $\begin{array}{c}\text { Ekstrak Air } \\
100 \mathrm{mg} / \mathrm{kg} \mathrm{BB}\end{array}$ & $104.17 \pm 7.58$ & $\begin{array}{c}114.13 \pm 33.74 \\
(8,76 \%)\end{array}$ & $\begin{array}{l}140.39 \pm 57.73 \\
(32,56 \%)\end{array}$ & $\begin{array}{c}92.35 \pm 28.81 \\
(-12,29 \%)^{\mathrm{a}}\end{array}$ \\
\hline $\begin{array}{l}\text { Fraksi Endapan Air } \\
100 \mathrm{mg} / \mathrm{kg} \mathrm{BB}\end{array}$ & $99.46 \pm 21.55$ & $\begin{array}{c}110.48 \pm 40.32 \\
(9,94 \%)\end{array}$ & $\begin{array}{l}117.39 \pm 39.00 \\
(17,86 \%)\end{array}$ & $\begin{array}{c}128.39 \pm 54.59 \\
(27,65 \%)^{\mathrm{a}}\end{array}$ \\
\hline $\begin{array}{l}\text { Fraksi EtOH } \\
100 \mathrm{mg} / \mathrm{kg} \mathrm{BB}\end{array}$ & $98.85 \pm 32.34$ & $\begin{array}{l}115.25 \pm 16.06 \\
(22,04 \%)\end{array}$ & $\begin{array}{c}107.30 \pm 22.53 \\
(11,77 \%)\end{array}$ & $\begin{array}{l}105.42 \pm 59.13 \\
(0,65 \%)^{\mathrm{a}}\end{array}$ \\
\hline $\begin{array}{l}\text { Fraksi EtOAc } \\
100 \mathrm{mg} / \mathrm{kg} \mathrm{BB}\end{array}$ & $81.04 \pm 131.48$ & $\begin{array}{c}131.48 \pm 14.61 \\
(65,85 \%)\end{array}$ & $\begin{array}{c}112.03 \pm 11.23 \\
(40,64 \%)\end{array}$ & $\begin{array}{c}107.29 \pm 21.22 \\
(32,48 \%)\end{array}$ \\
\hline $\begin{array}{l}\text { Fraksi Endapan EtOH } \\
100 \mathrm{mg} / \mathrm{kg} \mathrm{BB}\end{array}$ & $103.00 \pm 40.23$ & $\begin{array}{c}124.22 \pm 61.30 \\
(17,48 \%)\end{array}$ & $\begin{array}{c}133.90 \pm 69.80 \\
(25,56 \%)\end{array}$ & $\begin{array}{c}89.41 \pm 58.63 \\
(-18,4 \%)^{a}\end{array}$ \\
\hline $\begin{array}{l}\text { Fraksi n-Heksana } \\
100 \mathrm{mg} / \mathrm{kg} \mathrm{BB}\end{array}$ & $85.51 \pm 21.40$ & $\begin{array}{c}124.20 \pm 51.72 \\
(43,94 \%)\end{array}$ & $\begin{array}{c}138.29 \pm 93.79 \\
(52,94 \%)\end{array}$ & $\begin{array}{c}135.82 \pm 109.72 \\
(46,62 \%)\end{array}$ \\
\hline
\end{tabular}

Keterangan:

- $(\ldots . \%)$ adalah persen perubahan glukosa darah terhadap glukosa darah normal

- Berbeda nyata dibandingkan dengan glukosa darah kelompok kontrol $(P \leq 0.05)$

- Kadar glukosa darah mencit normal adalah kadar glukosa ke-0

- Ekstrak/fraksi diberikan secara oral langsung setelah pengambilan darah ke-0 (normal)

- Larutan glukosa 2 mg/Kg BB diberikan 1 jam setelah pemberian ekstrak/fraksi

- Pengambilan darah ke-1, 2, dan 3 jam dihitung setelah pemberian glukosa

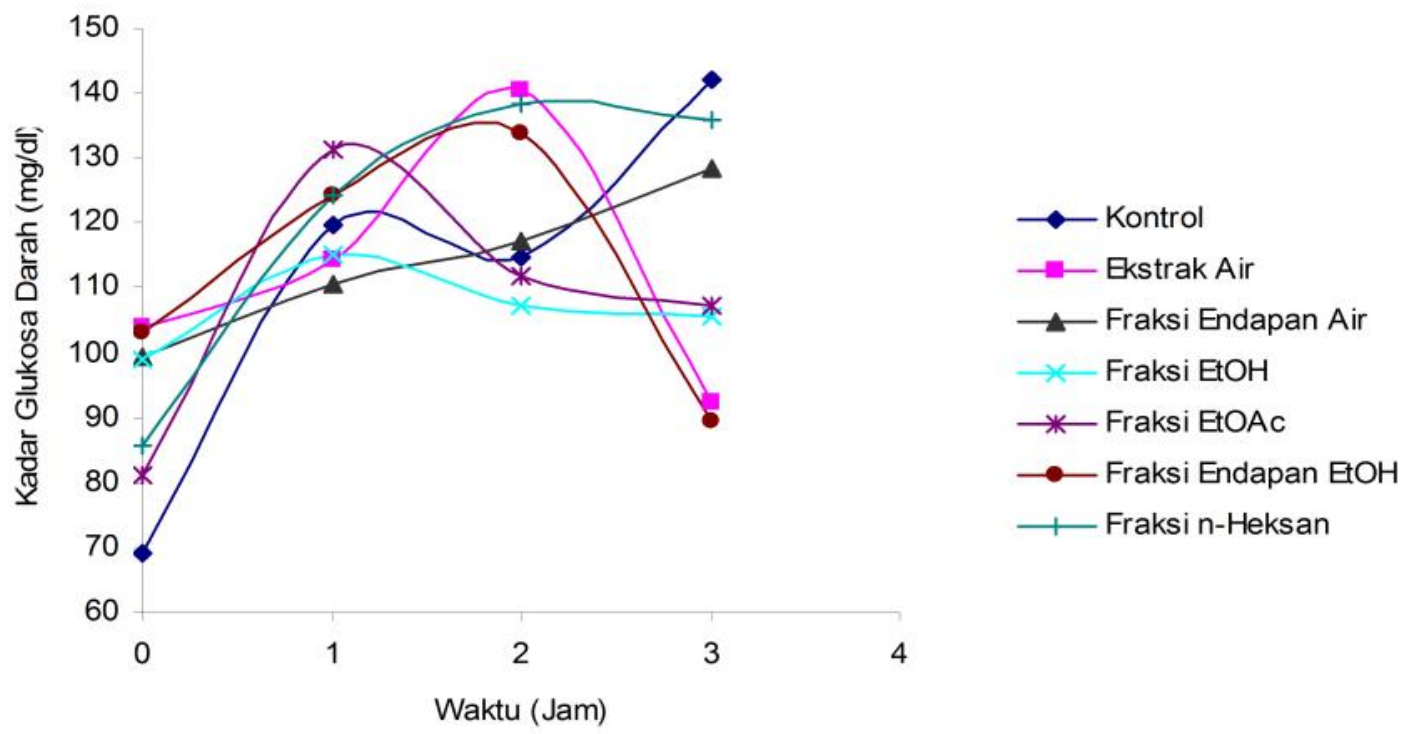

Gambar 6. Persen perubahan kadar glukosa darah mencit akibat pemberian ekstrak dan fraksi daun dandang gendis dengan metode toleransi glukosa

normal dengan metode toleransi glukosa (Suryawati \& Santosa, 1993). Perubahan kadar glukosa darah dari masing-masing kelompok pada jam ke-1 dan ke-2 setelah pemberian glukosa belum berbeda nyata terhadap kontrol. Sedangkan pada jam ke-3, kelompok ekstrak air, fraksi endapan air, fraksi Etanol, dan fraksi endapan etanol berbeda nyata terhadap kontrol pada $\mathrm{P}<0,05$ (selang kepercayaan 95\%). Pemilihan ekstrak atau fraksi yang akan diuji lebih lanjut didasari pada ekstrak atau fraksi yang memberikan kecepatan penurunan kadar glukosa darah paling tinggi yaitu yang memiliki penurunan kadar glukosa darah mendekati normal. Tabel 3 dan Gambar 2 menunjukkan bahwa pada perubahan glukosa darah dari normal (jam ke-0) ke jam ke-3 terlihat bahwa ekstrak air dan fraksi endapan Etanol memberikan penurunan kadar glukosa darah hingga $12,29 \%$ dan $18,4 \%$ di bawah kadar glukosa darah awal, sehingga penapisan diteruskan pada ekstrak air atau fraksi endapan etanol. Dilihat dari kandung metabolit sekunder, kelompok senyawa yang terkandung dalam ekstrak air dan fraksi endapan etanol adalah sama yaitu alkaloid, flavonoid, steroid/ triterpenoid, dan tanin. Karena adanya pemisahan lebih lanjut pada proses ekstraksi dan fraksinasi maka ekstrak atau fraksi yang diteruskan untuk diteliti adalah fraksi endapan etanol karena dianggap telah 
Tabel 4. Karakteristik fraksi endapan $\mathrm{EtOH}$ daun dandang gendis pada $\mathrm{KLT}$ pengembang $\mathrm{EtOH} 95 \%-\mathrm{CHCl}_{3}$ 9:2

\begin{tabular}{cccccc}
$\begin{array}{c}\text { No. } \\
\text { Fraksi }\end{array}$ & $\begin{array}{c}\text { Rendemen } \\
\text { Fraksi } \\
(\%)\end{array}$ & Noda & Warna & Rf Noda & Uji Kualitatif \\
\hline 1 & 11,11 & a & Hijau Kekuningan pada sinar tampak & 0,14 & Steroid \\
2 & 1,34 & d & Hijau Gelap di bawah sinar UV 254 & 0,77 & Triterpenoid \\
3 & 2,2 & b & Hijau Gelap di bawah sinar UV 254 & 0,53 & Steroid \\
& & K & Kuning di bawah sinar UV 366 & 0,67 & Flavonoid \\
& & d & Hijau Gelap di bawah sinar UV 254 & 0,77 & Triterpenoid \\
4 & 4 & b & Hijau Gelap di bawah sinar UV 254 & 0,53 & Steroid \\
& & C & Kuning di bawah sinar UV 366 & 0,67 & Flavonoid \\
5 & 1,53 & e & Merah di bawah sinar UV 366 & 0,89 & Klorofil \\
\hline
\end{tabular}

mengeliminasi senyawa semi polar dan non polar (ditarik oleh pengekstrak etilasetat dan n-heksana).

Fraksi endapan etanol dipisahkan lebih lanjut dengan menggunakan metode pemisahan kromatografi preparatif menggunakan plat silika gel preparatif ukuran $20 \times 10 \mathrm{~cm}$, dengan jarak tempuh $16 \mathrm{~cm}$, pengembang etanol 95\%-kloroform 9:2. Komposisi pengembang diperoleh dari percobaan pendahuluan mencari pengembang terbaik pada plat KLT analitik. Noda hasil pemisahan dideteksi di bawah lampu Ultraviolet 254 dan $366 \mathrm{~nm}$. KLT menggunakan pengembang ini menunjukkan 5 noda di bawah sinar lampu Ultraviolet 254 dan $366 \mathrm{~nm}$ (Tabel 4).

KLT masing-masing fraksi dan uji kualitatif dengan pereaksi spesifik dan penampakan di bawah sinar UV 254 dan $366 \mathrm{~nm}$ menunjukkan fraksi 1 (golongan senyawa steroid) memiliki satu noda memanjang dengan $\mathrm{Rf} 0,14$. Fraksi 2 (golongan senyawa triterpenoid) memiliki satu noda dengan $\mathrm{Rf}$ 0,77 dan fraksi 3 (golongan senyawa triterpenoid dan flavonoid) memiliki 3 noda dengan Rf 0,52; 0,67; dan 0,77. Fraksi 4 memiliki dua noda dengan $\mathrm{Rf} 0,53$ dan 0,67 yang merupakan senyawa golongan steroid dan flavonoid. Sedangkan fraksi 5 (klorofil) memiliki satu noda dengan Rf 0,89.

\section{KESIMPULAN}

Ekstrak air daun dandang gendis (Clinacanthus nutans) dosis $150 \mathrm{mg} / \mathrm{kg}$ bb dapat menurunkan kadar glukosa darah mencit diabetes induksi aloksan. Hal ini menunjang penggunaan di masyarakat sebagai antidiabetes. Fraksi endapan etanol yang memiliki kandungan senyawa metabolit sekunder yang sama dengan ekstrak air yaitu flavonoid, steroid/triterpenoid, dan tanin memberikan penurunan kadar glukosa darah mencit dengan metode toleransi glukosa paling besar dibandingkan fraksi lain.

\section{UCAPAN TERIMA KASIH}

Terima kasih kepada PEMDA Provinsi Riau atas bantuan dana yang diberikan kepada penulis.

\section{DAFTAR PUSTAKA.}

Andarini, R. M. 1990. Efek ekstrak daun Dandang Gendis (Clinacanthus nutans) terhadap fungsi hati tikus. Skripsi Fakultas Farmasi. Yogyakarta: UGM

Laurence, D. R. \& Bacharach, A. L. 1964. Evaluation of Drug Activities Pharmacometrics Volume. London: Academic press.. Halaman 161.

Lee, H. W., Park, Y. S., Choi, J. W., Yi, S. Y., \& Shin, W. S. 2003. Antidiabetic effects of chitosan oligosaccharides in neonatal streptozotocin-induced noninsulin-dependent diabetes mellitus in rats. Biol. Pharm. Bull. 26(8): 1100-1103.

Natalia, S. 1992. Pemeriksaan farmakognosi dan golongan kandungan kimia dari Clinacanthus nutans (Burm. F) Lindau, Skripsi. Surabaya: Fakultas Farmasi Widman.

Setiawan, L. \& Suryaatmadja, M. 2003. Evaluasi kinerja glukosameter One Touch Ultra ${ }^{R}$ dan penggunaannya untuk pengukuran kadar glukosa darah lengan. Bagian Patologi Klinik FKUI Perjan RSCM, Jakarta.

Soemardji, A. A. 2004. Penentuan kadar gula darah mencit secara cepat dalam penapisan aktivitas antidiabetes in vivo. Acta Pharmaceutica Indonesia. XXIX(3): 115-116

Sugiri, I. I. 1980. Penelitian mengenai adanya khasiat hipoglikemik dari daun Clinacanthus nutans (Dandang Gendis) dan kulit Alstonia patulata (basung). Skripsi. Bandung: Departemen Kimia FMIPA ITB.

Suharty, N. S. 1984. Isolasi terpenoid dari daun Clinacanthus nutans. Tesis. Bandung: Program Magister Kimia Pasca Sarjana ITB.

Suryawati, S. \& Santosa, B. 1993. Penapisan Farmakologi, Pengujian Fitokimia, dan Pengujian klinik. Jakarta: Yayasan Pengembangan Obat Bahan Alam Phytomedica 